\title{
My Reading and Writing Experiences: Snowball
}

\author{
Mengjiao Zhao ${ }^{1}$
}
Writing across the University of Alberta, $2021^{2}$
Volume 2, pp. 7-12
Published December 2021

Keywords: learning English, literacy narrative, language teachers

Whenever I think back on my past experience of learning to read and write, I find that this process was like snowballing. I was very grateful to the several English teachers I had met since my childhood. They have appeared at different stages of my life and have seen me grow. If my goal in life was to roll a big snowball, then they were undoubtedly the biggest help in my life.

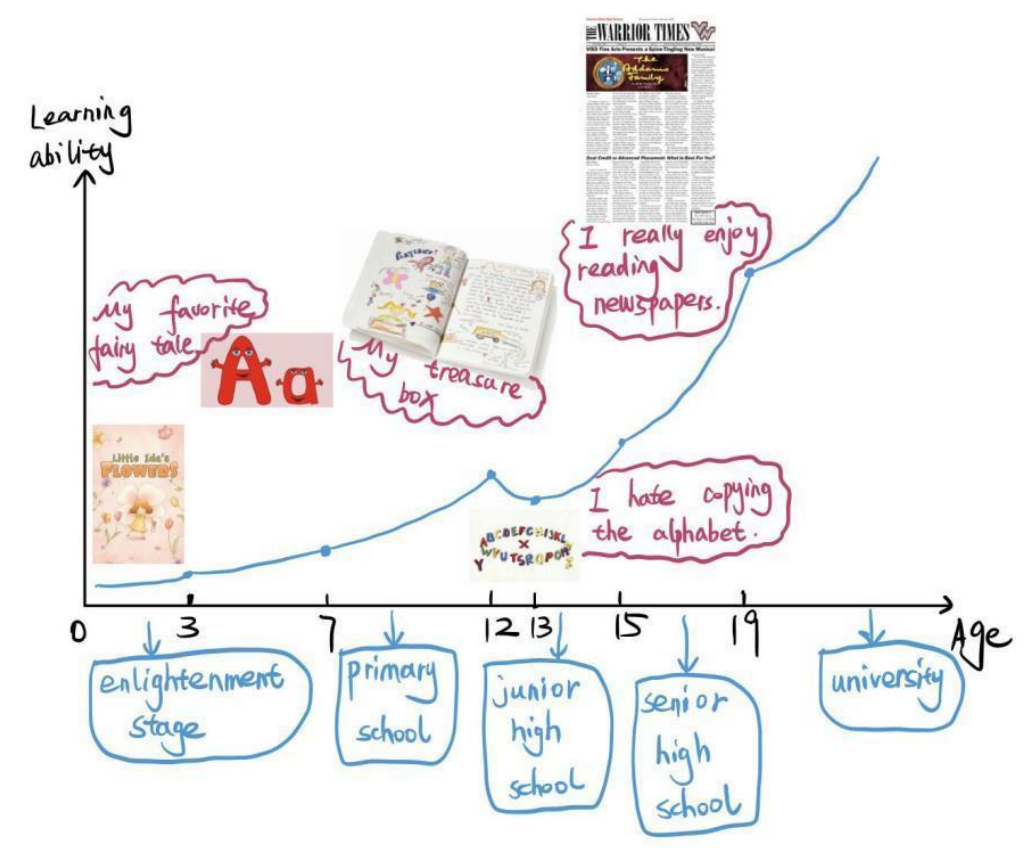

Figure 1: My process of learning English 


\section{Part 1: The First Snowball in My Life (Enlightenment)}

You would never believe that I bought my first storybook at a children's hospital. When I was young, my mother often needed to take me to the hospital for vaccinations, but to calm my nerves, as I was so afraid of injections, my mother would reward me with a picture book every time I was vaccinated. There was a glass window in the lobby on the first floor of the hospital with all kinds of children's books in it. The first picture book with typeface in my life was Hans Christian Andersen's Fairy Tales. Since I didn't know how to read at that time, my mother would tell me stories when I was nervous, and the first story she read to me was "The Flowers of Little Ida." What impressed me most were the smiling faces of the flowers in the illustrations of the story. Many people might think these illustrations were childish, but for me, who was afraid of injections, the smiling faces of the flowers had given me great comfort at that time. This story remained number one on my list of favourite and most memorable stories to date.

I wanted to thank my mother. Because she read me those interesting storybooks, I discovered that writing could bring so much warmth to people. If the storybook was the snow all over the ground, my mother made me the first snowball in my life. At that moment, I saw the beauty of a snowball for the first time in my life. Then, a bold idea came into my mind - I want a bigger snowball.

\section{Part 2: Snowballing Slope (Primary School)}

When I was in the third grade, I met Anna, who was my first English teacher. "Don't forget to keep an English diary!" Anna would remind me. It was one of my childhood nightmares, and I heard it almost every day before school. For me at the time, it was a very difficult task to write an English diary every day. At first, I was really worried about the diary's contents every day, because I didn't know what to write. I had to write down what I did every day, like a journal account, to finish my homework. I hated writing because the process of writing was boring. Even though I didn't like reading my diary, I thought it was a waste of my life to spend time writing these things. Therefore, I decided to talk to Anna with a little trepidation.

"Honey, you can write whatever you want. Why not broaden your mind?" Anna said to me softly.

Anna's words reminded me immediately. Why did I have to write about my daily life? I could write about anything if I wanted to.

After that, I began to think about the contents of my daily diary seriously. When I felt I had no idea what to do, I sat quietly and observed my surroundings. Sometimes on my way 
home, I would watch the direction of the trees swaying in the wind, and sometimes I would squat under the trees and listen to the cuckoo.

"John, look at the way the cypress trees are swaying in the wind. Do you think they're welcoming us home for the weekend?" I said to John.

"What did you say? I don't think so. They're just shaking," replied John. Whenever I shared how I felt about observing things around me with my friends, they thought my ideas were strange. I didn't know if I was too sensitive, but I enjoyed the feeling, and these seemingly ordinary things also gave me a lot of inspiration and material.

I would write these findings and feelings in my English diary, and then I found that Anna would write her feelings at the bottom of my diary every time. But, most importantly, she would also draw me a smiley face every time. I liked this smiling face very much because it gave me more encouragement and confidence. After that, I gradually fell in love with writing.

Of course, I sometimes used diary writing to vent my emotions (because only I could see it). Over time, diary writing became a habit of mine, and the diary was like my treasure box, full of my various growing-up experiences. When I was in fourth grade, Anna became an English teacher in another class.

Since I was a very sensitive person by nature, most of the time, my classmates and friends couldn't understand my ideas, so that as time passed, I began to doubt whether I was born different from others. This idea had troubled me for many years. Finally, however, I accidentally learned some of journalist Donald Murray's (2005) writing habits through my university writing course, and I found that the habits of awareness he mentioned were consistent with my observation habits. At that moment, I felt so excited because I finally met someone who had the same habits as me. After that, I began to apply this writing habit more in my writing process.

I guess diary writing was my earliest exposure to free writing. I liked this free way of writing very much. Now I still could open my diary from time to time. I often thought the ideas in my diary were childish, and there were many misspelled words and bad grammar. I didn't think anyone other than me could understand my diary content. However, the content of the diary was my best memory.

Keeping a diary stimulated my interest in writing, and it also allowed me to understand myself better. I was grateful to Anna because she helped me find a long slope filled with thick snow, making my snowballs roll up naturally.

\section{Part 3: Why Was My Snowball Getting Smaller? (Junior High School)}

At this stage, I met Hathaway, a woman in her fifties, who was my worst English teacher by far. She was my English teacher for a whole year when I was in the first grade of junior high school. During that year, our daily homework was copying the alphabet. In 
Hathaway's class, you could easily find that most of the students were doing other things besides learning English because her class was boring, and she seldom taught us some substantive content. Therefore, in that year, my reading and writing abilities had no improvement. On the contrary, I thought my English ability also regressed a lot (because I forgot many words and writing methods that I had learned before). Fortunately, I transferred to my high school in the second year.

If knowledge was the snow all over the ground, then I thought the snowfield that Hathaway provided me was unsuitable for me (there was too little snow). Although my snowball was smaller than before, I was still very grateful to Hathaway because she taught me the importance of a good snowfield for snowballing.

\section{Part 4: How Did My Snowball Get Bigger? (High School)}

"Do you have any better ideas for this problem?" My classmate asked me. If you went to high school with me, you would hear it at least ten times a day in my English class.

When I was in high school, I met Serena, who was an excellent English teacher. Every day, she would let us read English newspapers and some biographies of people and make comments on the books. To be honest, in the beginning, I was very uncomfortable with the learning method of reading while annotating. Still, after a long period of practice, my reading ability had improved a lot. Reading English newspapers allowed me to learn a lot of new words, while comments deepened my understanding of the article's content. Moreover, whenever I turned to my previous reading notes, I would immediately remember my thoughts and feelings at the time. Therefore, this was a very good way to learn English.

In her English class, I always needed to keep up my spirits. I felt her class was like a marathon; although you would feel exhausted at the end, you would get a sense of achievement. Serena divided us into different groups, and we always had a heated discussion about the exercises in the English newspaper.

"Okay, which group is going to talk about this?" Serena said to us. When Serena gave us a chance to answer questions, we would scramble to raise our hands because, at the end of each semester, she would reward the group that had done well in class (students who performed well could get rid of writing summer homework). However, I always thought I was holding my team back because my English score was very poor at the beginning, and I was always at the bottom of the class. Therefore, I felt that I couldn't keep up with the pace of our group during this time. As a result, I had low self-esteem, and I never dared to speak up in class.

Serena seemed to feel what was going on inside me, so she called me into her office every day to help me with my lessons. When she was busy, she would ask another boy in our class who was very good at English to help me. Then, she would ask me to do a lot of exercises for each knowledge point. After a lot of practice, my basic skills had become quite 
solid. Half a year later, I was among the top 15 students in my class out of a total of 70 . I was thrilled and grateful to Serena for helping me, and I became more confident than before. I began to like this way of competition. Although I was under a lot of pressure during that time (sometimes it even took my breath away), the pressure made me become a better person. Moreover, I still worked very hard to learn English because I set a higher goal for myself, inspiring me to constantly improve my English ability.

Serena gave me a lot of useful writing advice, but I didn't get used to making an outline before writing. However, in learning to write, when I read an article about freewriting written by the American writing studies scholar Peter Elbow (1973), I learned that he had the same views as I do. He said that if we had an outline before we write, it would limit our ability to generate new ideas. I quite agreed with him. So many of my best ideas came to me casually while I was writing, and I usually didn't know what to write if I outlined it before writing.

Serena also encouraged me to rewrite my essay a few years ago, but I didn't understand why. In most cases, I wouldn't rewrite it if it wasn't off-topic because I didn't think it made much sense to me. Not long ago, however, I had the opportunity to read Nancy Sommers' (1980) "Revision strategies of student writers and experienced adult writers," and some of the things she said in her article changed my view of rewriting. I realized that I hadn't figured out what I was trying to say most of the time. I just wrote, and what I wrote wasn't what the reader wanted to read. Sommers said we need to break out of my conventional thinking mode, think from a different perspective, and get used to the process of rewriting. Although this was very challenging for me, it made it more clear to me as to what I wanted to express.

I wanted to thank Serena for providing me with such a good snowfield and teaching me how to make my snowball roll faster. With her help, my snowball got bigger and bigger.

As I was learning reading and writing, I was fortunate to meet these several excellent teachers. Without their help, I couldn't find such a long slope and such a good snowfield. Now I have found a better snowfield (my university) and a longer slope, and my snowball was rolling fast there. 


\section{References}

Elbow, P. (1973). Writing without teachers. Oxford University Press.

Murray, D. (2005). A writer's habits. In M. E. Sargent \& C. C. Paraskevas (Eds.), Conversations about writing: Eavesdropping, inkshedding, joining in. (pp. 82-88). Nelson.

Sommers, N. (1980). Revision strategies of student writers and experienced adult writers. College Composition and Communication, 31(4), 378-388. https://doi.org/10.2307/356588

$(9) \bigoplus$ This work is licensed under CC BY-NC-ND 4.0. To view a copy of this license, visit https://creativecommons.org/licenses/by-nc-nd/4.0. 